\author{
Galyna Mykhalyna and Teodoziya Vrublevska
}

\title{
PECULIARITIES OF OSMIUM COMPOUNDS INTERACTION WITH SOME FLAVONOIDS
}

\author{
Ivan Franko National University of Lviv, \\ 6, Kyryla i M efodiya str., 79005 Lviv, Ukraine; galyna_myhalyna@yahoo.com
}

Received: October 03, 2010 / Revised: November 29, 2010 / Accepted: J anuary 31, 2011

(C) Mykhalyna G., Vrublevska T., 2011

\begin{abstract}
The interaction of Os(IV) ions with morin, quercetin, luteolin has been investigated and the spectrophotometric methods of osmium determination using these reagents have been elaborated. The influence of various factors and the maximum yield of the products of Os(IV) ions interaction with flavonoids have been determined. The change of electronic absorption spectra depending on the duration of the solution heating in a boiling water bath in the presence or absence of atmospheric oxygen as well as the interaction of osmium(II, III, VI and VIII) ions with flavonoids investigated have been shown. The redox nature of osmium(IV) ions interaction with morin and quercetin has been confirmed.
\end{abstract}

Keywords: osmium, flavonoids, spectrophotometry, reaction mechanism.

\section{Introduction}

Medicinal raw materials and pure flavonoids are widely spread in nature and find various applications. Many of them have P-vitamin activity, decrease fragility of blood capillaries, and strengthen the medicinal action of ascorbic acid. Flavonoids have anti-inflammatory and antiulcer action. They are antioxidants, some of them have spasmodic and choleretic action [1,2]. Their complexation reactions with some $p-, d-, f$-metals make them interesting analytical reagents. Quercetin and morin are widely applied for determining many metals [3, 4]. Luteolin forms complexes with $\mathrm{Fe}(\mathrm{II}), \mathrm{Fe}$ (III) and $\mathrm{Cu}$ (II) [5]. Structural formulas of the reagents are presented in Fig. 1.Besides complex formation at the interaction of flavonoids with metal ions, the process may proceed through the stage of intermediate compound formation with the following flavonoid oxidation and metal reduction [6]. Such process can be shown by the following scheme:

$$
\mathrm{A}+\text { complex }\left(\mathrm{M}_{\mathrm{n}} \mathrm{L}_{\mathrm{x}}\right) \underset{\text { unstable complex }}{\rightarrow}\left(\mathrm{M}_{\mathrm{n}} \mathrm{L}_{\mathrm{x}-1} \mathrm{~A}\right) \rightarrow \mathrm{A}_{1}+\left(\mathrm{M}_{\mathrm{n}-1} \mathrm{~L}_{\mathrm{x}}\right)
$$

where $\mathrm{L}$ - ligand, $\mathrm{A}$ - organic substrate, $\mathrm{A}_{1}$ - product of $\mathrm{A}$ oxidation, $\mathrm{M}_{\mathrm{n}-1} \mathrm{~L}_{\mathrm{x}}$ - complex of the reduced metal ion.

The interaction between the oxidized flavonoid $\left(\mathrm{A}_{1}\right)$ and the complex of reduced metal ion $\left(\mathrm{M}_{\mathrm{n}-1} \mathrm{~L}_{\mathrm{x}}\right)$ is not ruled out in such a scheme.

Redox behaviour of the ligand often depends on the position of the hydroxyl groups in a flavonoid structure [5]. Thus, while investigating the interaction of such reagents with metals ions it is necessary to take into account various factors which can influence the maximum yield of the components interaction product in the system investigated.<smiles>COc1cc(O)ccc1-c1oc2cc(O)cc(O)c2c(=O)c1O</smiles><smiles>O=c1c(O)c(-c2ccc(O)c(O)c2)oc2cc(O)cc(O)c12</smiles><smiles>O=c1cc(-c2ccc(O)c(O)c2)oc2cc(O)cc(O)c12</smiles>

Fig. 1. Structural formulas of the utilized flavonoids 
It is especially applied to osmium, which also forms coloured compounds with the above mentioned flavonoids [7, 8]. Osmium possesses interesting and individual properties (refractoriness, hardness, wear and corrosion resistance), great ability to oxidation-reduction processes in the presence of many organic and inorganic reagents and the variety of existence forms in aqueous solutions [9-11]. Just these properties make it possible to use osmium in modern engineering, in carrying out histological researches, organic synthesis and other branches, in spite of osmium toxicity, especially its volatile tetraoxide, which irritates mucous membrane and respiration organs even in minute quantities, affects skin and eyes [12].

Actuality of the search of new perspective reagents for osmium determination is mainly caused by its minute amounts in the Earth crust and the presence of one or few platinum group elements in real samples. The control of osmium content in mineral raw materials, industrial products and wastes by means of accessible, expressive, sensitive and selective methods is of great importance for the development of the analytical chemistry of platinum group elements. Such samples may contain the analyte in a wide concentration range $[9,10]$. Flavonoids appeared to be effective spectrophotometric reagents for osmium determination.

The aim of the present work was to determine the influence of some factors on osmium (IV) ions interaction with flavonoids in order to understand peculiarities of such interaction.

\section{Experimental}

\subsection{Reagents}

All aqueous solutions were prepared using distilled water.

Stock solution of osmium(IV) $\left(\mathrm{H}_{2} \mathrm{OsCl}_{6}\right)$ was prepared by dissolving the exact mass of $\mathrm{OsO}_{4}$ (analytical grade) from a hermetically sealed glass ampoule in the concentrated hydrochloric acid, following the modified method [13]. The obtained osmium solution was stored for 1 month for the complete transferring of Os(VIII) into Os(IV), because $\mathrm{OsO}_{4}$ is rapidly reduced to $\mathrm{OsCl}_{6}{ }^{2-}$ on heating and slowly at room temperature [14]. Standard working solutions of Os(IV) were prepared by dissolving an aliquot of Os(IV) initial stock solution in ca. $0.5-1 \mathrm{~mol} \cdot \mathrm{l}^{-1} \mathrm{HCl}$ aqueous solution up to $\mathrm{pH}<1$. According to Ref. [10], $\mathrm{OsCl}_{6}{ }^{2-}$ does not undergo hydrolysis under room temperature in the media of hydrochloric acid, when $\mathrm{C}_{\mathrm{HCl}}>0.5 \mathrm{~mol} \cdot \mathrm{l}^{-1}$.

The solutions of morin (LOBA CHEMIE, Czech Republic), quercetin (CHEMAPOL, Czech Republic) and luteolin (Ukrainian Scientific Centre of Medicines Quality, Ukraine) were prepared by the dissolving the exact mass of the reagent in $96 \%$ v/v ethanol.
The solutions of hydrochloric and nitric acids, sodium hydroxide, sodium chloride and sodium tetraborate were prepared from the chemicals of the analytical grade.

\subsection{Apparatus}

UV-Vis absorbance measurements were performed with a UV-VIS scanning spectrophotometer CARY.WIN UV-Vis-50 (Varian, USA), SPECORD M40 (Germany) and photometer KFK-2 - UHL 4.2 (Zagorsky MechanicalOptical Plant, Russia) using $1-5 \mathrm{~cm}$ cuvettes. All absorbance measurements were performed at $c a .293 \mathrm{~K}$. pH measurements were carried out with a $\mathrm{pH}$-meter, model pH-150 M (Gomelsky Plant of Measuring Devices, Belarus), equipped with a glass electrode. $\mathrm{pH}$ of each solution was adjusted using diluted $\mathrm{HCl}$ and $\mathrm{NaOH}$ solutions.

\subsection{Standardization and Identification of Osmium (IV) Solutions}

In order to establish an exact concentration of the obtained $\mathrm{OsCl}_{6}{ }^{2-}$ solution, a standardization was carried out titrimetrically using $\mathrm{KI}$ as a titrant; the generated $\mathrm{I}_{2}$ was back-titrated with standardized $\mathrm{Na}_{2} \mathrm{~S}_{2} \mathrm{O}_{3}$ :

$$
\begin{aligned}
& 2 \mathrm{Os}^{4+}+2 \mathrm{I}^{-} \text {(excess) } \rightarrow 2 \mathrm{Os}^{3+}+\mathrm{I}_{2}, \\
& \mathrm{I}_{2}+2 \mathrm{~S}_{2} \mathrm{O}_{3}{ }^{2-} \rightarrow 2 \mathrm{I}^{-}+\mathrm{S}_{4} \mathrm{O}_{6}{ }^{2-} .
\end{aligned}
$$

The identification of osmium(IV) solutions was carried out spectrophotometrically by comparing the recorded electronic absorption spectra (Fig. 2) with the literature data $[15,16]$.

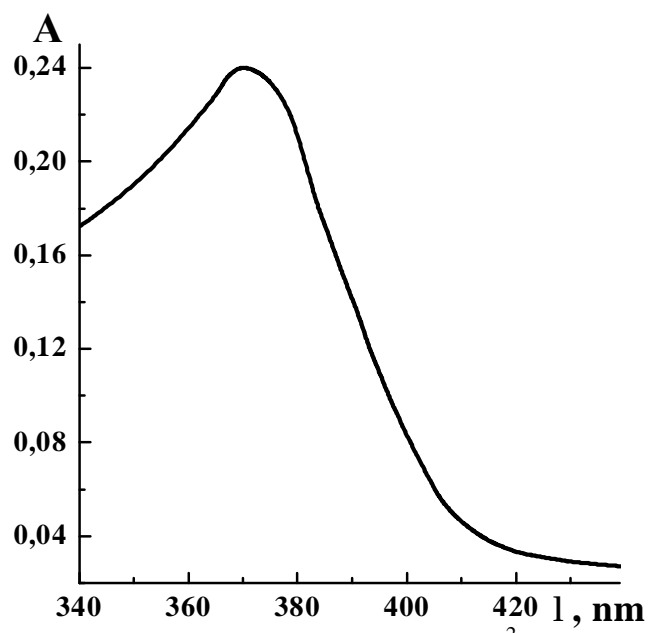

Fig. 2. Absorption spectrum of $\mathrm{OsCl}_{6}^{2-}$ solution; $C_{\mathrm{Os}(\mathrm{IV})}=3.78 \cdot 10^{-3} \mathrm{~mol} \mathrm{l}^{-1}, C_{\mathrm{HCl}}=1.0 \mathrm{~mol} \cdot 1^{-1}$

As it followed from the obtained spectra, in standard stock solutions of osmium(IV) the ionic form of $\mathrm{OsCl}_{6}^{2-}$ dominates. 
3. Results and Discussion

\subsection{Spectrophotometry of Osmium(IV) Interaction Products with Flavonoids}

As it has been experimentally established, flavonoids enter reactions with osmium(IV) ions forming coloured compounds. Morin forms two absorption bands at $335 \mathrm{~nm}$ and a visible spectral range at $485 \mathrm{~nm}$ in the alkaline media (Fig. 3).

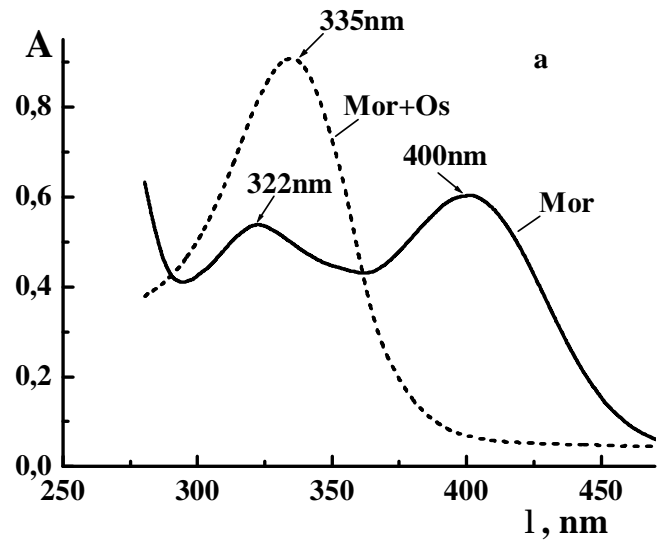

Quercetin also reacts with the analyte in the alkaline medium, while luteolin reacts in a weakly acidic medium at $\mathrm{pH}=6$, although the formation of absorbance shoulder within the wavelength of $400-500 \mathrm{~nm}$ is inherent for both quercetin and luteolin in the presence of Os(IV) ions (Figs. 4 and 5). These spectral regions were used for the investigations, where the maximum difference between the absorbance of the reagent and its compounds with osmium(IV).

Fig. 3. Absorption spectra of morin solutions and products of $\mathrm{Os}(\mathrm{IV})$ interaction with morin: $C_{\mathrm{Os}(\mathrm{IV})}=3.0 \cdot 10^{-6} \mathrm{~mol} \cdot \mathrm{l}^{-1}$,

$$
C_{\mathrm{Mor}}=3.0 \cdot 10^{-5} \mathrm{~mol} \cdot \mathrm{l}^{-1} \text { (a) and } C_{\mathrm{Os}(\mathrm{IV})}=1.5 \cdot 10^{-5} \mathrm{~mol} \cdot 1^{-1}, C_{\mathrm{Mor}}=1.5 \cdot 10^{-4} \mathrm{~mol} \cdot \mathrm{l}^{-1} \text { (b). }
$$
$\mathrm{pH}=9.5 ; C\left(\mathrm{Na}_{2} \mathrm{~B}_{4} \mathrm{O}_{7}\right)=1.2 \cdot 10^{-4} \mathrm{~mol} \cdot 1^{-1} ; l=1 \mathrm{~cm}$

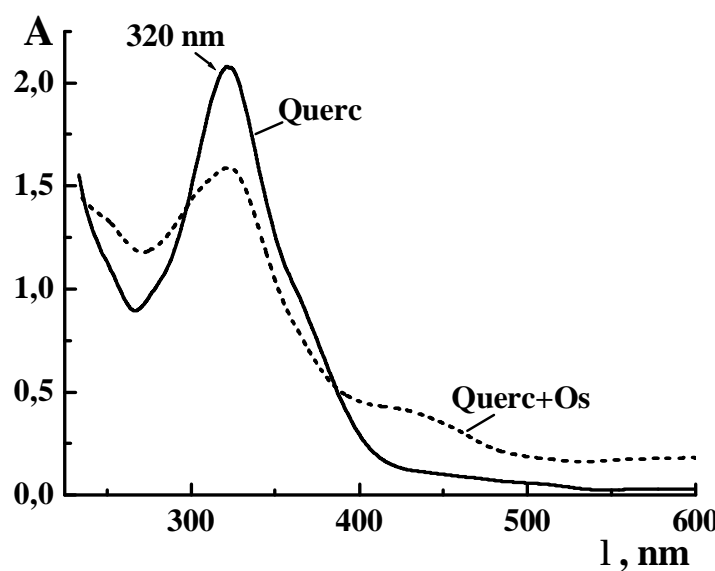

Fig. 4. Absorption spectra of quercetin and Os(IV)-quercetin compound; $\mathrm{pH}=10.0 ; l=1 \mathrm{~cm} ; C_{\mathrm{Os}(\mathrm{IV})}=1.5 \cdot 10^{-5} \mathrm{~mol} \cdot \mathrm{l}^{-1}$; $C_{\text {Querc }}=9.0 \cdot 10^{-5} \mathrm{~mol} \cdot 1^{-1} ; C(\mathrm{NaCl})=0.1 \mathrm{~mol} \cdot \mathrm{l}^{-1}$

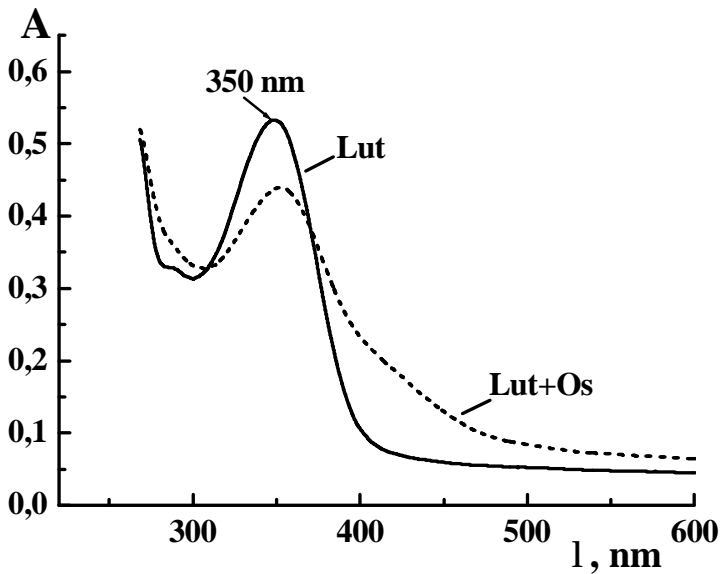

Fig. 5. Absorption spectra of luteolin and Os(IV)-luteolin compound; $\mathrm{pH}=6.0 ; l=1 \mathrm{~cm} ; C_{\mathrm{Os}(\mathrm{IV})}=1.5 \cdot 10^{-5} \mathrm{~mol} \cdot \mathrm{l}^{-1}$; $C_{\text {Lut }}=2.3 \cdot 10^{-5} \mathrm{~mol} \cdot 1^{-1} ; C(\mathrm{NaCl})=0.1 \mathrm{~mol} \cdot 1^{-1} ; 10 \% \mathrm{v} / \mathrm{v} \mathrm{C}_{2} \mathrm{H}_{5} \mathrm{OH}$

The conditions of the formation and some characteristics of osmium (IV) compounds with flavonoids

\begin{tabular}{|c|c|c|c|c|c|c|}
\hline System & $\lambda_{\max }, \mathrm{nm}$ & $\mathrm{pH}_{\text {opt }}$ & Medium & $\tau_{\text {heating }}, \min$ & Reagent's excess & $\varepsilon_{\lambda} \cdot 10^{-4}, 1 \cdot \mathrm{mol}^{-1} \cdot \mathrm{cm}^{-1}$ \\
\hline Os(IV)-Mor & 335 & $9.5-10.0$ & \multirow{2}{*}{$1.2 \cdot 10^{-4} \mathrm{M} \mathrm{Na}_{2} \mathrm{~B}_{4} \mathrm{O}_{7}$} & 3 & 10 -fold & 16.2 \\
\cline { 1 - 3 } Os(IV)-Mor & 485 & $9.3-9.5$ & 30 & 10 -fold & 1.5 \\
\hline Os(IV)-Quer & 440 & $9.5-10.3$ & $0.1 \mathrm{M} \mathrm{NaCl}$ & 6 & 8 -fold & 1.3 \\
\hline Os(IV)-Lut & 400 & $6.0-6.5$ & $\begin{array}{c}10 \% \mathrm{v} / \mathrm{v} \mathrm{C} \mathrm{C}_{5} \mathrm{OH}, \\
0.1 \mathrm{M} \mathrm{NaCl}\end{array}$ & $*$ & 1 -fold & 0.74 \\
\hline
\end{tabular}

*-compound is formed at room temperature (291-295 K) 
The validation parameters of osmium(IV) spectrophotometric determination with flavonoids

\begin{tabular}{|l|c|c|c|c|}
\hline \multirow{2}{*}{ System } & $\begin{array}{c}\text { Linear range } \\
C_{\mathrm{Os}}, \mu \mathrm{g} \cdot \mathrm{ml}^{-1}\end{array}$ & $\begin{array}{c}\text { Regression equation of } \\
\text { calibration plot, } \\
C_{\mathrm{Os}}, \mu \mathrm{g} \cdot \mathrm{ml}^{-1}\end{array}$ & $\begin{array}{c}\text { Limit of } \\
\text { quantification, } \\
\mu \mathrm{g} \cdot \mathrm{ml}^{-1}\end{array}$ & $\begin{array}{c}\text { Correlation } \\
\text { coefficient, } R\end{array}$ \\
\hline \multirow{3}{*}{ Os(IV)-morin } & $0.006-0.036$ & $\Delta \mathrm{A}_{335}=0.021+2.45 \times \mathrm{C}_{\mathrm{Os}}$ & & 0.9982 \\
\cline { 2 - 3 } & $0.07-0.72$ & $\Delta \mathrm{A}_{485}=0.005+0.309 \times \mathrm{C}_{\mathrm{Os}}$ & 0.004 & 0.9991 \\
\cline { 1 - 5 } & $0.85-4.30$ & $\Delta \mathrm{A}_{485}=0.197+0.075 \times \mathrm{C}_{\mathrm{Os}}$ & & 0.9999 \\
\hline Os(IV)-quercetin & $0.18-1.45$ & $\Delta \mathrm{A}_{440}=-0.031+0.358 \times \mathrm{C}_{\mathrm{Os}}$ & 0.120 & 0.9992 \\
\hline Os(IV)-luteolin & $0.45-11.50$ & $\Delta \mathrm{A}_{400}=0.035+0.062 \times \mathrm{C}_{\mathrm{Os}}$ & 0.350 & 0.9984 \\
\hline
\end{tabular}

The optimum conditions of photometric measurements and some spectrophotometric characteristics of the obtained compounds are presented in Table 1.

The validation parameters of osmium(IV) spectrophotometric determination with flavonoids are given in Table 2. According to the tabular data, the sensitivity of osmium determination differs depending on the nature of the reagent. The reaction of osmium with morin is the most sensitive, at $335 \mathrm{~nm}$ it can be determined up to $0.004 \mu \mathrm{g} \cdot \mathrm{ml}^{-1}$, but at $485 \mathrm{~nm}$ the quantification of an analyte can be carried out in the wide concentration range. Therefore, when analysing real samples it is possible to choose the conditions for carrying out the experiments depending on the quantity of osmium and the presence of foreign components in such samples.

\subsection{The Influence of Heating on the Formation of Osmium (IV) Compounds with Flavonoids}

Taking into account the substantial kinetic inertness of the initial complex $\left[\mathrm{OsCl}_{6}\right]^{2-}$, its interaction with morin and quercetin takes place after thermal activation of solutions and after mixing of the reagents (Fig. 6), while the

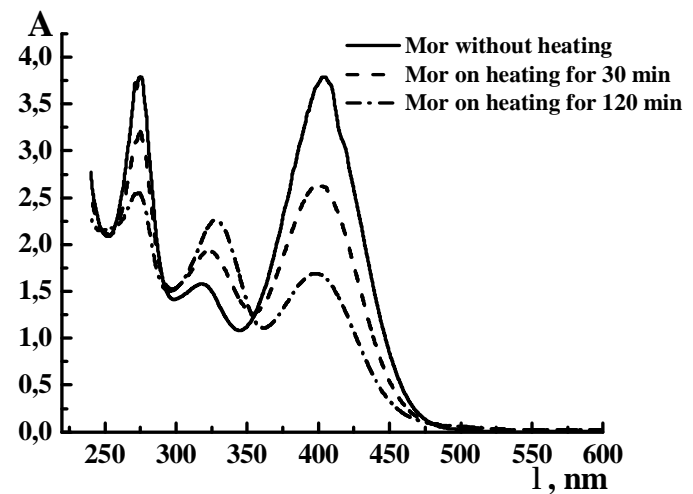

Fig. 7. Absorption spectra of morin solutions depending on heating time on a boiling water bath $\left(\mathrm{pH}=9.5 ; C\left(\mathrm{Na}_{2} \mathrm{~B}_{4} \mathrm{O}_{7}\right)=1.2 \cdot 10^{-4} \mathrm{~mol} \cdot \mathrm{l}^{-1} ; l=1 \mathrm{~cm} ;\right.$

$$
C_{\mathrm{Mor}}=1.5 \cdot 10^{-4} \mathrm{~mol} \cdot \mathrm{l}^{-1} \text { ) }
$$

interaction of osmium (IV) with luteolin occurs at room temperature.

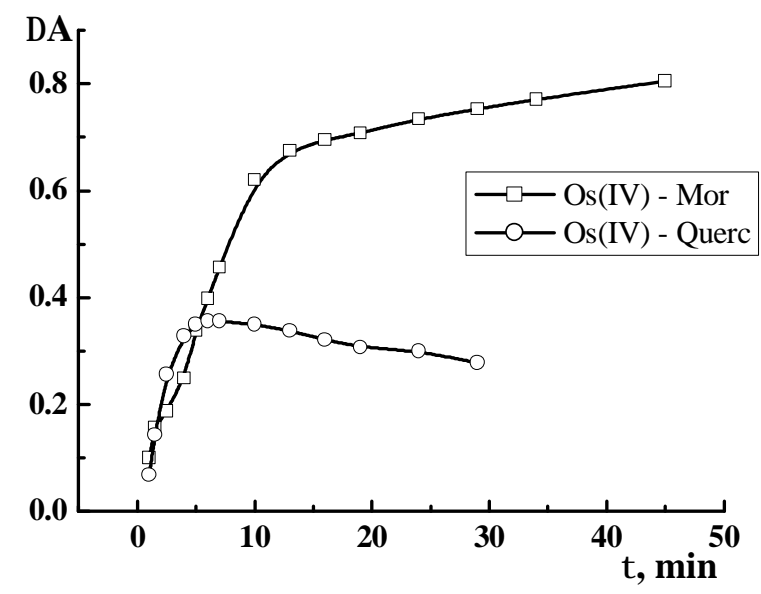

Fig. 6. The influence of heating time $(\sim 371 \mathrm{~K})$ on the maximum yield of coloured osmium(IV) compounds with morin at $485 \mathrm{~nm}$ $\left(C_{\mathrm{Os}(\mathrm{IV})}=1.5 \cdot 10^{-5} \mathrm{~mol} \cdot \cdot^{-1} ; C_{\mathrm{Mor}}=1.5 \cdot 10^{-4} \mathrm{~mol} \cdot \cdot^{-1} ;\right.$

$\left.C\left(\mathrm{Na}_{2} \mathrm{~B}_{4} \mathrm{O}_{7}\right)=1.2 \cdot 10^{-4} \mathrm{~mol} \cdot \mathrm{l}^{-1} ; \mathrm{pH}=9.5\right)$ and quercetin at $440 \mathrm{~nm}$

$\left(C_{\mathrm{Os}(\mathrm{IV})}=7.5 \cdot 10^{-6} \mathrm{~mol} \cdot \mathrm{l}^{-1} ; C_{\text {Quer }}=6.0 \cdot 10^{-5} \mathrm{~mol} \cdot 1^{-1}\right.$;

$\left.C(\mathrm{NaCl})=0.1 \mathrm{~mol} \cdot l^{-1} ; \mathrm{pH}=10.0\right) ; l=3 \mathrm{~cm}$

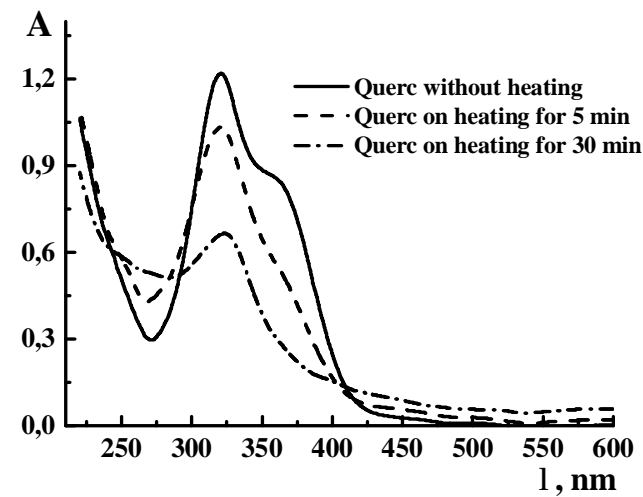

Fig. 8. Absorption spectra of quercetin solution depending on heating time on a boiling water bath $\left(\mathrm{pH}=10.0 ; C(\mathrm{NaCl})=0.1 \mathrm{~mol} \cdot \mathrm{l}^{-1} ; l=1 \mathrm{~cm} ;\right.$

$$
\left.C_{\text {Quer }}=9.0 \cdot 10^{-5} \mathrm{~mol} \cdot l^{-1}\right)
$$


The spectral changes of morin and quercetin solutions under optimum investigation conditions depending on the duration of heating on boiling water bath $(\sim 371 \mathrm{~K})$ is shown in Figs. 7 and 8.

As it is shown on the electronic absorption spectra (Figs. 7 and 8), the decrease of absorption maxima is observed under heating the solutions of these reagents, which confirms their partial oxidation with atmospheric oxygen. But their character differs from the absorption spectra of the investigated flavonoids in the presence of Os(IV) ions (Figs. 3-5). Concerning the stability of the formed analytical forms, the value of the analytical signal remains stable within two hours in all cases, and the product with morin at $485 \mathrm{~nm}$ is stable within few days.

\subsection{The Role of Atmospheric Oxygen at the Formation of the Products of Osmium (IV) Interaction with Flavonoids}

Taking into account the substantial antioxidant properties of flavonoids and the ability of Os(IV, VI and VIII) ions to act as a catalyst of oxidation processes of organic reagents by atmospheric oxygen [17], the formation of the products of osmium(IV) interaction with flavonoids in

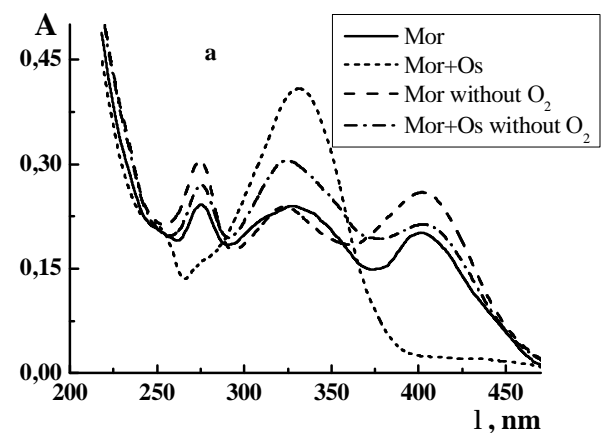

the presence of oxygen and in the oxygen free media has been investigated (the dissolved oxygen was removed by the barbotage of argon within $15 \mathrm{~min}$ through the solutions of the reagents before heating them on the boiling water bath). Obtained experimental results are shown in Figs. 9-11.

As it is seen from the presented plots, for the system of Os(IV)-Mor the maximum yield is observed in the presence of atmospheric oxygen, while in the oxygen free media the absorbance band at $485 \mathrm{~nm}$ is not formed at all, but at $335 \mathrm{~nm} \Delta \mathrm{A}$ increases slightly. The similar situation is observed for the system Os(IV)-Quer, that is, the formation of absorbance shoulder is not observed in the oxygen free media. Therefore, oxidation of these flavonoids by atmospheric oxygen is evident. Here Os(IV) acts as the catalyst with the further formation of the coloured compounds. Very high sensitivity of osmium determination with morin can be explained by the catalytic nature of the reaction. As for the interaction of luteolin with Os (IV) ions, probably, the complexation reaction occurs, since the value of analytical signal on the absorbance shoulder increases slightly in the oxygen free media. That is, in this case flavonoids oxidation reaction is competitive and influences negatively the formation process of coloured complex compound.

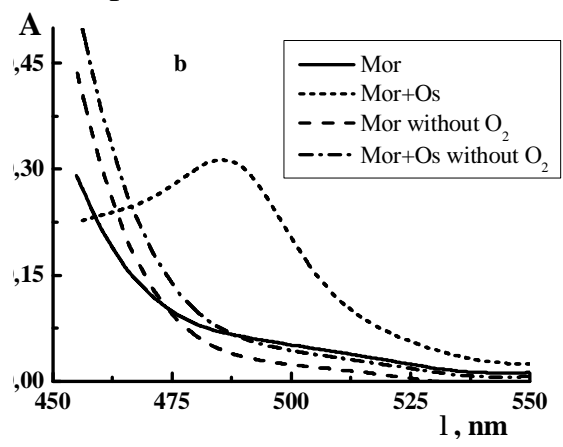

Fig. 9. Absorption spectra of morin and the products of Os(IV) interaction with morin, obtained in the presence and in the absence of atmospheric oxygen $\left(\mathrm{pH}=9.5 ; l=1 \mathrm{~cm} ; C\left(\mathrm{Na}_{2} \mathrm{~B}_{4} \mathrm{O}_{7}\right)=1.2 \cdot 10^{-4} \mathrm{~mol} \cdot \mathrm{l}^{-1}\right): C_{\mathrm{Os}(\mathrm{IV})}=1.5 \cdot 10^{-6} \mathrm{~mol} \cdot \mathrm{l}^{-1} ; C_{\mathrm{Mor}}=1.5 \cdot 10^{-5} \mathrm{~mol} \cdot \mathrm{l}^{-1} ; \tau_{\text {heating }}=3 \mathrm{~min}(\mathrm{a})$ and $C_{\mathrm{Os}(\mathrm{IV})}=1.5 \cdot 10^{-5} \mathrm{~mol} \cdot \mathrm{l}^{-1} ; C_{\mathrm{Mor}}=1.5 \cdot 10^{-4} \mathrm{~mol} \cdot \mathrm{l}^{-1} ; \tau_{\text {heating }}=30 \mathrm{~min}(\mathrm{~b})$

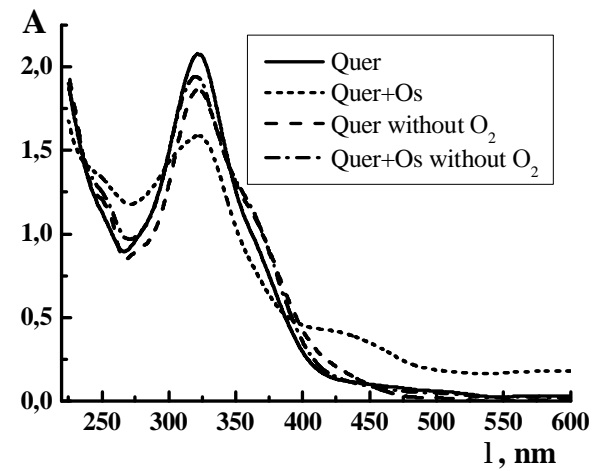

Fig. 10. Absorption spectra of quercetin and Os(IV)-quercetin compound, obtained in the presence and in the absence of atmospheric oxygen

$$
\begin{gathered}
\left(l=1 \mathrm{~cm} ; C_{\mathrm{Os}(\mathrm{IV})}=1.5 \cdot 10^{-5} \mathrm{~mol} \cdot 1^{-1} ; C_{\mathrm{Quer}}=9.0 \cdot 10^{-5} \mathrm{~mol} \cdot \mathrm{l}^{-1} ;\right. \\
\left.C(\mathrm{NaCl})=0.1 \mathrm{~mol} \cdot \mathrm{l}^{-1} ; \mathrm{pH}=10.0\right)
\end{gathered}
$$

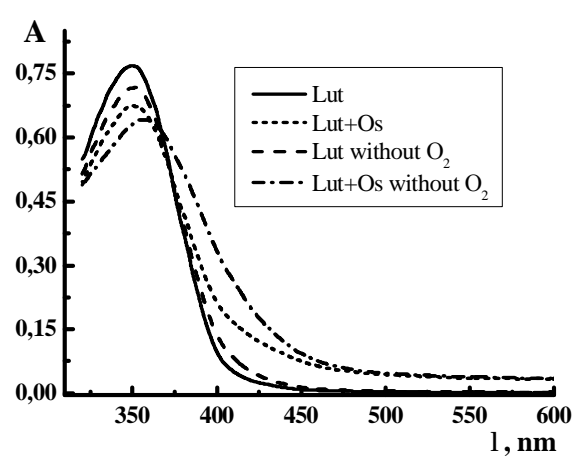

Fig. 11. Absorption spectra of luteolin and Os(IV)-luteolin compound, obtained in the presence and in the absence of atmospheric oxygen $\left(\mathrm{pH}=6.0 ; l=1 \mathrm{~cm} ; C_{\mathrm{Os}(\mathrm{IV})}=1.5 \cdot 10^{-5} \mathrm{~mol} \cdot \mathrm{l}^{-1}\right.$;

$$
C_{\mathrm{Lut}}=2.3 \cdot 10^{-5} \mathrm{~mol} \cdot \mathrm{l}^{-1} \text {; }
$$

$\left.10 \% \mathrm{v} / \mathrm{v} \mathrm{C}_{2} \mathrm{H}_{5} \mathrm{OH} ; C(\mathrm{NaCl})=0.1 \mathrm{~mol} \cdot \mathrm{l}^{-1}\right)$ 


\subsection{Interaction of Osmium(II, III, VI, VIII) Ions with Flavonoids}

Considering the redox nature of osmium interaction with flavonoids, we compared the electronic absorption spectra of the products of their interaction with Os(II, III, IV, VI, VIII), which differ by their oxidation-reduction potentials (Table 3) [9, 10, 18].

Os(II), Os(III) and Os(VIII) were obtained under the action of chloride acidic hydrohylamine [19], ascorbic acid [19-21] and concentrated nitric acid on Os(IV) solutions, respectively. Os(VI) was obtained at the dissolution of $\mathrm{OsO}_{4}$ in $5 \mathrm{M}$ solution of $\mathrm{KOH}$ [9]. The obtained spectra are presented in Fig. 12-14.

According to the obtained electronic absorption spectra, oxidants Os(IV), Os(VI) and Os(VIII) interact with morin and quercetin in a similar way. The spectra of these polyphenols with Os(II) and Os(III), oxidizing properties of which are substantially weaker, almost do not differ from the spectra of the reagent, except morin, which interacts with all forms of osmium at $335 \mathrm{~nm}$, except Os(III) (Fig. 12), that can

Table 3

Standard oxidation-reduction potentials of the systems in acidic and neutral mediawith osmium at various oxidation states

\begin{tabular}{|l|c|c|c|}
\hline Higher oxidation state & $+\mathrm{ne}$ & Lower oxidation state & $E^{0}, \mathrm{~V}$ \\
\hline $\mathrm{Os}^{2+}$ & $+2 \overline{\mathrm{e}}$ & $\mathrm{Os} \downarrow$ & 0.55 \\
\hline $\mathrm{OsCl}_{6}{ }^{3-}$ & $+3 \overline{\mathrm{e}}$ & $\mathrm{Os} \downarrow+6 \mathrm{Cl}^{-}$ & 0.71 \\
\hline $\mathrm{OsCl}_{6}{ }^{3-}$ & $+\overline{\mathrm{e}}$ & $\mathrm{Os}^{2+}+6 \mathrm{Cl}^{-}$ & 0.40 \\
\hline $\mathrm{OsCl}_{6}{ }^{2-}$ & $+\overline{\mathrm{e}}$ & $\mathrm{OsCl}_{6}{ }^{3-}$ & 0.85 \\
\hline $\mathrm{OsO}_{4}+6 \mathrm{Cl}^{-}+8 \mathrm{H}^{+}$ & $+4 \overline{\mathrm{e}}$ & $\mathrm{OsCl}_{6}{ }^{2-}+4 \mathrm{H}_{2} \mathrm{O}$ & 0.96 \\
\hline $\mathrm{OsO}_{4}+8 \mathrm{H}^{+}$ & $+8 \overline{\mathrm{e}}$ & $\mathrm{Os} \downarrow+4 \mathrm{H}_{2} \mathrm{O}$ & 0.85 \\
\hline
\end{tabular}
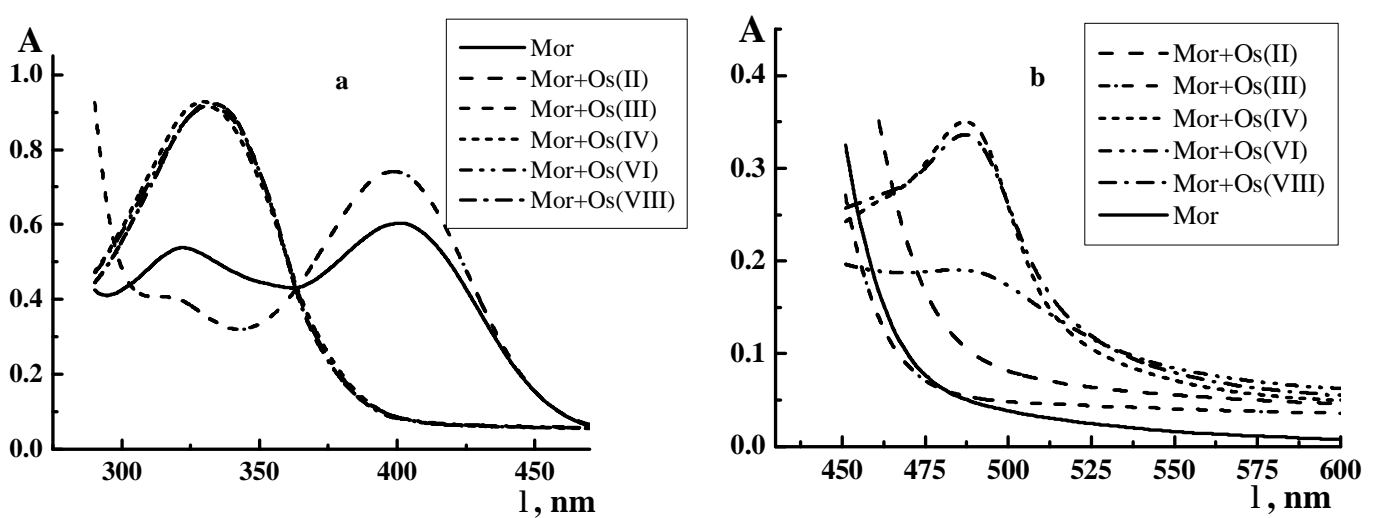

Fig. 12. Absorption spectra of morin and the products of morin interaction with Os(IV, II, III, VI, VIII); $C\left(\mathrm{Na}_{2} \mathrm{~B}_{4} \mathrm{O}_{7}\right)=1.2 \cdot 10^{-4} \mathrm{~mol} \cdot \mathrm{l}^{-1}$; $l=1 \mathrm{~cm} ; \mathrm{pH}=9.5: C_{\mathrm{Os}(\mathrm{IV})}=C_{\mathrm{Os}(\mathrm{II})}=C_{\mathrm{Os}(\mathrm{III})}=C_{\mathrm{Os}(\mathrm{VII})}=C_{\mathrm{Os}(\mathrm{VIII})}=3.0 \cdot 10^{-6} \mathrm{~mol} \cdot \mathrm{l}^{-1} ; C_{\mathrm{Mor}}=3.0 \cdot 10^{-5} \mathrm{~mol} \cdot 1^{-1} ; \tau_{\text {heating }}=3 \mathrm{~min}$ (a) and $C_{\mathrm{Os}(\mathrm{IV})}=$ $=C_{\mathrm{Os}(\mathrm{II})}=C_{\mathrm{Os}(\mathrm{III})}=C_{\mathrm{Os}(\mathrm{VI})}=C_{\mathrm{Os}(\mathrm{VIII})}=1.5 \cdot 10^{-5} \mathrm{~mol} \cdot \mathrm{l}^{-1}, C_{\mathrm{Mor}}=1.5 \cdot 10^{-4} \mathrm{~mol} \cdot 1^{-1}, \tau_{\text {heating }}=30 \mathrm{~min}$ (b)

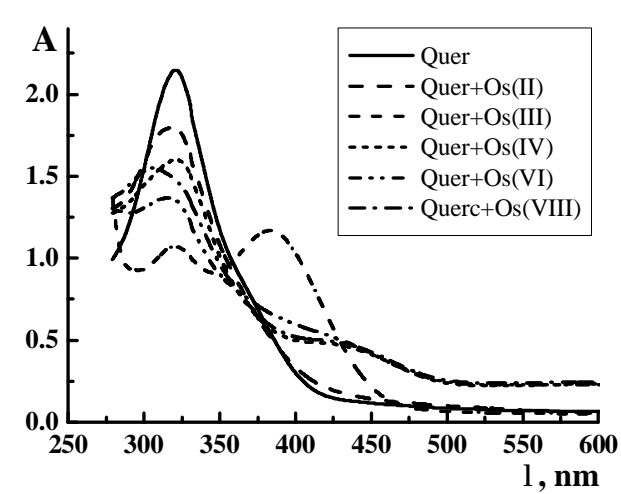

Fig. 13. Absorption spectra of quercetin and its compounds with Os(IV, II, III, VI, VIII); $\mathrm{C}_{\mathrm{Os}(\mathrm{IV})}=C_{\mathrm{Os}(\mathrm{II})}=C_{\mathrm{Os}(\mathrm{III})}=C_{\mathrm{Os}(\mathrm{VI})}$ $=C_{\mathrm{Os}(\mathrm{VIII})}=1.5 \cdot 10^{-5} \mathrm{~mol} \cdot \mathrm{l}^{-1}, C_{\mathrm{Quer}}=9.0 \cdot 10^{-5} \mathrm{~mol} \cdot \mathrm{l}^{-1}$; $\mathrm{pH}=10.0, l=1 \mathrm{~cm}, C(\mathrm{NaCl})=0.1 \mathrm{~mol} \cdot \mathrm{l}^{-1}$

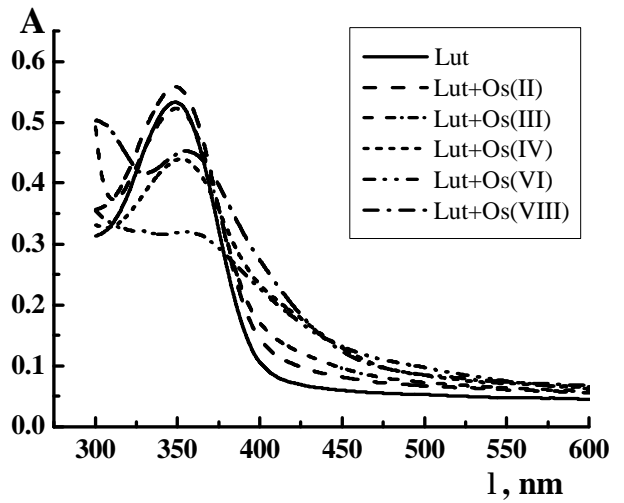

Fig. 14. Absorption spectra of luteolin and its compounds with $\mathrm{Os}(\mathrm{IV}, \mathrm{II}, \mathrm{III}, \mathrm{VI}, \mathrm{VIII}) ; C_{\mathrm{Os}(\mathrm{IV})}=C_{\mathrm{Os}(\mathrm{II})}=C_{\mathrm{Os}(\mathrm{III})}=$ $=C_{\mathrm{Os}(\mathrm{VI})}=C_{\mathrm{Os}(\mathrm{VIII})}=1.5 \cdot 10^{-5} \mathrm{~mol} \cdot 1^{-1}, C_{\mathrm{Lut}}=2.3 \cdot 10^{-5} \mathrm{~mol} \cdot \mathrm{l}^{-1}$; $\mathrm{pH}=6.0, C(\mathrm{NaCl})=0.1 \mathrm{~mol} \cdot \mathrm{l}^{-1}, 10 \% \mathrm{v} / \mathrm{v} \mathrm{C}_{2} \mathrm{H}_{5} \mathrm{OH}, l=1 \mathrm{~cm}$ 


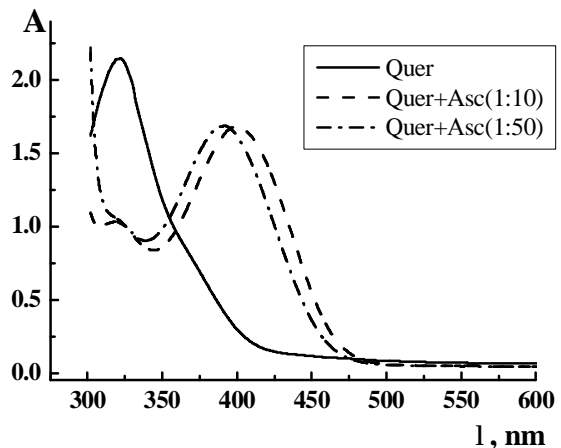

Fig. 15. Absorption spectra of quercetin in the presence of various quantities of ascorbic acid (Asc) and in its absence $\left(\mathrm{pH}=10.0 ; l=1 \mathrm{~cm} ; C_{\text {Quer }}=9.0 \cdot 10^{-5} \mathrm{~mol} \cdot \cdot^{-1} ;\right.$
$\left.C(\mathrm{NaCl})=0.1 \mathrm{~mol} \cdot \cdot^{-1}, \tau_{\text {teating }}=6 \mathrm{~min}\right)$

be connected with the specific action of ascorbic acid on the interaction of osmium with all flavonoids, by means of which Os(III) can be obtained in the solution, according to the methods [19-21]. That is why it is impossible to affirm the absence of interaction between morin, quercetin and Os(III). The influence of ascorbic acid on these flavonoids taking quercetin as the example is given in Fig. 15.

In the case of luteolin, osmium ions interact at all oxidation stages and the value of absorbance increases from Os (II) to Os (VIII) (Fig. 13). The influence of ascorbic acid on such interaction is smaller, the decrease of the absorbance is observed at its 50-fold excess, showing another nature of interaction, namely complex formation.

The obtained results confirm the redox nature of the interaction between morin and quercetin and also the catalytic role of osmium ions at the formation of coloured compound.

\section{Conclusions}

It has been established, that osmium(IV) ions interact with morin and quercetin in the alkaline medium on heating on the boiling water bath, while they interact with luteolin in the weakly acidic medium at room temperature. It has been shown, that the sensitivity of osmium determination and the mechanism reaction depend on the flavon nature and the conditions for carrying out the reaction. The role of atmospheric oxygen at the interaction of Os (IV) ions with flavonoids has been investigated and it has been stated that in the oxygen free medium the interaction takes place only with luteolin. The interaction of morin, quercetin and luteolin with osmium at various oxidation states under optimum conditions of Os(IV) ions interaction with these flavonoids has been investigated for the first time. The oxidants Os(VI) and Os(VIII) interact with flavonoids in the same way as Os(IV) does, while Os(II) interacts with luteolin only slightly and forms the band with morin at $335 \mathrm{~nm}$. To test the possibility of Os(III) ions to form compounds with morin and quercetin was not successive because of a negative influence of ascorbic acid, and Os(III) ions interact weakly with luteolin.

\section{References}

[1] Sereda P., Maksyutina N. and Davtyan L.: Farmakogniziya. Likarska Roslynna Syrovyna ta Fitozasoby. Nova Knyga, Vinnytsya 2006.

[2] Durshmishidze S., Shalashvili A., Mzhavanadze V. and Tsyklauri G.: Flavonoidy i Oksy-Korychniye Kisloty Nekotorykh Predstavitelei Dikorastushchei Flory Gruzii. Metsniereba, Tbilisi 1981.

[3] Burger K.: Organicheskiye Reagenty v Neorganicheskom Analize. Mir, Moskwa 1975.

[4] Balcerzak M. and Kus S.: Anal. Sci., 2004, 20, 1333.

[5] Kostyuk V., Potapovich A., Strigunova E. et al.: Biochem. \& Biophysics, 2004, 2, 204.

[6] Kopacz M., Kuzniar A., Nowak D. and Kopacz S.: Materialy VI Ogolnopolskej Konferencji "Flawonoidy i ich zastosowanie", Rzeszów 2006, 253.

[7] Mykhalyna G., Vrublevska T. and Korkuna O.: Visn. Lviv Univ. Ser. Khim., 2009, 50, 170.

[8] Rydchuk M., Mykhalyna G., Bonishko O. et al.: Chem. of Metals and Alloys, 2009, 2, 89.

[9] Ginzburg S., Yezerskaya N., Prokofyeva I. et al.: Analiticheskaya Khimiya Platinovyh Metallov. Nauka, Moskwa 1972.

[10] Zolotov Yu., Varshal G. and Ivanov V. (Eds.): Analiticheskaya Knimiya Metallov Platinivoy Gruppy. Collected articles. Izd-vo URSS, Moskwa 2003.

[11] Hartley F. (Ed.): Chemistry of the Platinum Group Metals. Recent Developments. Elsevier, Amsterdam 1991.

[12] Lazarev N. and Gadaskina I. (Eds.): Vredniye Veshchestva v Promishlennosti. Spravochnik dlya Khimikov, Inzhenerov i Vrachey, T. III, Khimiya, Leningrad 1977.

[13] Turner A., Clifford A. and Ramachandra Rao C.: Anal. Chem., 1958, 30, 1708.

[14] Balcerzak M. and Swiecicka E.: Talanta, 1996, 43, 471.

[15] Miano R. and Garner C.: Inorg. Chem., 1965, 4, 337.

[16] Alimarin I., Khvostova V. and Kadyrova G.: Zh. Analit. Khim., 1975, 30, 2007.

[17] Mushtakova S., Kraskova T. and Gumenyuk A.: Zh. Analit. Khim., 1988, 43(11), 2014.

[18] Lurye Yu.: Spravochnik po Analiticheskoy Knimiyi. Khimiya, Moskwa 1989.

[19] Bonishko O.: PhD thesis, Lviv 2008.

[20] Pirogov A. and Havel J.: J. Chromatogr. A., 1997, 772, 347.

[21] Zhang H.-W., Jia L. and Hu Z.-D.: J. Chromatogr. A., 1995, 704, 242.

\section{ОСОБЛИВОСТІ ВЗАЕМОДІЇ СПОЛУК ОСМІЮ 3} ДЕЯКИМИ ФЛАВОНОЇДАМИ

Анотація. Досліджено взаємодію йонів осмію (IV) з морином, кверцетином, лютеоліном та розроблено спектрофотометричні методики його визначення з використанням ицих реагентів. Вивчено вплив різних чинників на максимальний вихід продуктів взаємодії йонів Os (IV) з флавоноїдами: показано зміну електронних спектрів абсорбиії в залежності від тривалості нагрівання розчинів на киплячій водяній бані, у присутності та за відсутності кисню повітря, а також взаємодію йонів осмію (II, III, VI ma VIII) 3 досліджуваними флавоноїдами. Підтверджено окисно-відновну природу взаємодї йонів осмію (VI) з морином та квериетином.

Ключові слова: осмій, флавоноїди, спектрофотометрія, механізм реакиїі. 